\title{
EFFECT OF PROPOLIS HONEY CANDY CONSUMPTION ON THE ACTIVITY OF LACTOPEROXIDASE IN STIMULATED SALIVA
}

\author{
SYARIFAH RAHMI ${ }^{1}$, AGOENG TJAHAJANI SARWONO ${ }^{2 *}$, SRI ANGKY SOEKANTO ${ }^{2}$ \\ ${ }^{1}$ Undergraduate Program, Faculty of Dentistry, Universitas Indonesia, Jakarta 10430, Indonesia. ${ }^{2}$ Department of Periodontics, Faculty of \\ Dentistry, Universitas Indonesia, Jakarta 10430, Indonesia. Email: agoeng.tjahajani@gmail.com
}

Received 14 October 2018, Revised and Accepted 12 January 2019

ABSTRACT

Objective: This study aimed to analyze the effect of propolis honey candy consumption on lactoperoxidase (LPO) activity in stimulated saliva.

Methods: Stimulated saliva samples were collected from subjects before and after propolis honey candy consumption twice a day for 7 days, and the LPO activity was measured by optical density using a microplate reader.

Results: The LPO activity before and after propolis honey candy consumption was found to be 0.010 and 0.013 , respectively.

Conclusions: A statistically significant increase in the LPO activity after propolis honey candy consumption was observed (Wilcoxon test; $\mathrm{p}<0.05)$.

Keywords: Propolis, Lactoperoxidase, Saliva, Flavonoids.

(C) 2019 The Authors. Published by Innovare Academic Sciences Pvt Ltd. This is an open access article under the CC BY license (http://creativecommons. org/licenses/by/4. 0/) DOI: http://dx.doi.org/10.22159/ijap.2019.v11s1.AR184

\section{INTRODUCTION}

Propolis (beeswax) is a sticky, dark brown, mixed resin material that is collected by honey bees from various plants. Propolis is not only used to create beehives, but also has many benefits for human health $[1,2]$. In the past, propolis was used to make medicine in Egypt and as a chemical in the mummification process for corpses [2]. Propolis is proven to have various biological activities such as antibacterial, antifungal, antiviral, anti-inflammatory, antitumor, and antioxidant activities $[3,4]$.

Propolis consists of $50 \%$ resin, 30\% wax, $10 \%$ essential and aromatic oils, $5 \%$ pollen, and $5 \%$ other substances [4]. Flavonoids have antibacterial activity, which inhibits bacterial growth through destruction of cell walls, microsomes, and lysosome permeability, as a result of the interaction between flavonoids and the host DNA. This leads to decreased production of hydrogen peroxide $\left(\mathrm{H}_{2} \mathrm{O}_{2}\right)$ by bacteria. This decreasing amount of $\mathrm{H}_{2} \mathrm{O}_{2}$ can inhibit enzyme activities such as increasing lactoperoxidase (LPO) in saliva [5].

Saliva consists of $99.5 \%$ water and $0.5 \%$ inorganic and organic materials, one of which is protein (non-immunoglobulin and immunoglobulin) [6]. One of the non-immunoglobulin proteins is peroxidase, which forms the peroxidase system [7]. There are two types of peroxidase in saliva, LPO and myeloperoxidase that exhibit bacteriostatic effects [8]. Both of the enzymes use $\mathrm{H}_{2} \mathrm{O}_{2}$ as the substrate, whereas they use different cosubstrate ions [8].

LPO is an important oxidative enzyme in saliva because saliva itself does not have antimicrobial activity. However, a combination of LPO, thiocyanate ion $\left(\mathrm{SCN}^{-}\right.$, cosubstrate from saliva), and $\mathrm{H}_{2} \mathrm{O}_{2}$ (bacterial product) can produce a hypothiocyanate ion $\left(\mathrm{OSCN}^{-}\right)$, which acts as an antibacterial agent [7]. The mechanism of LPO is based on the amount of $\mathrm{H}_{2} \mathrm{O}_{2}$. If this amount is decreased, then $\mathrm{SCN}^{-}$cannot be oxidized. This leads to an ineffective antibacterial system for LPO. Antibacterial application, such as that exhibited by propolis, can inhibit $\mathrm{H}_{2} \mathrm{O}_{2}$ production as well as inhibit LPO activity [9].

Many studies have demonstrated the application of propolis in dentistry. However, to the best of our knowledge, there is no research about propolis candy and LPO activity in stimulated saliva. Therefore, this research was conducted to determine the effect of propolis candy on LPO activity in stimulated saliva and its effectiveness in decreasing LPO activity compared with honey candy and X candy.

\section{METHODS}

This research was a clinical experiment in the laboratory at Faculty of Dentistry, Universitas Indonesia, from August to November 2014. A total of 120 subjects participated. The inclusion criteria were as follows: 19-23 years old, good medical condition, good oral condition, and willingness to participate in this research and provide informed consent. The exclusion criteria included fixed orthodontic appliances, periodontal disease, smoking, dentures, systemic disease that manifested in oral condition, bad oral hygiene, allergic to propolis, alcohol consumption, and medications such as antibiotics.

Subjects were screened to examine oral health. The stimulated saliva was obtained in the morning before consuming candy and 1 week later after routinely consuming candy twice a day for 7 days. Before collecting sample, subjects were instructed not to eat and drink (except mineral water) for a minimum of $1.5 \mathrm{~h}$ after brushing teeth, then subjects chewed paraffin chewing gum, and saliva was collected in a $50 \mathrm{ml}$ tube with a funnel for $10 \mathrm{~min}$. Each tube was coded and put into a cooler to be processed at the laboratory.

Saliva was transferred from the $50 \mathrm{ml}$ tube to a $1.5 \mathrm{ml}$ microtube. The saliva was then subjected to centrifugation at $15.000 \times \mathrm{g}$ for $20 \mathrm{~min}$ at $4^{\circ} \mathrm{C}$. The supernatant from natant (pellet) was transferred into another $1.5 \mathrm{ml}$ microtube. The microplate was prepared, $100 \mu \mathrm{l}$ phosphate buffer $+50 \mu \mathrm{KI}+50 \mu \mathrm{l}$ stimulated saliva supernatant $+2 \mu \mathrm{l} \mathrm{H}_{2} \mathrm{O}_{2}$ were added into well plate (by triplo), and $100 \mu \mathrm{l}$ aquades mixed with same reagent were added by triplo into the well plate as a blank (control). Then, the plate was incubated for $30 \mathrm{~min}$ in dark. The microplate reader was observed at $340 \mathrm{~nm}$ wavelength, the mixture was shaken for $10 \mathrm{~s}$, and well mapping was set. The optical density (OD) of LPO in saliva was measured with the following formula: Saliva absorbance - blank absorbance $=$ OD. 


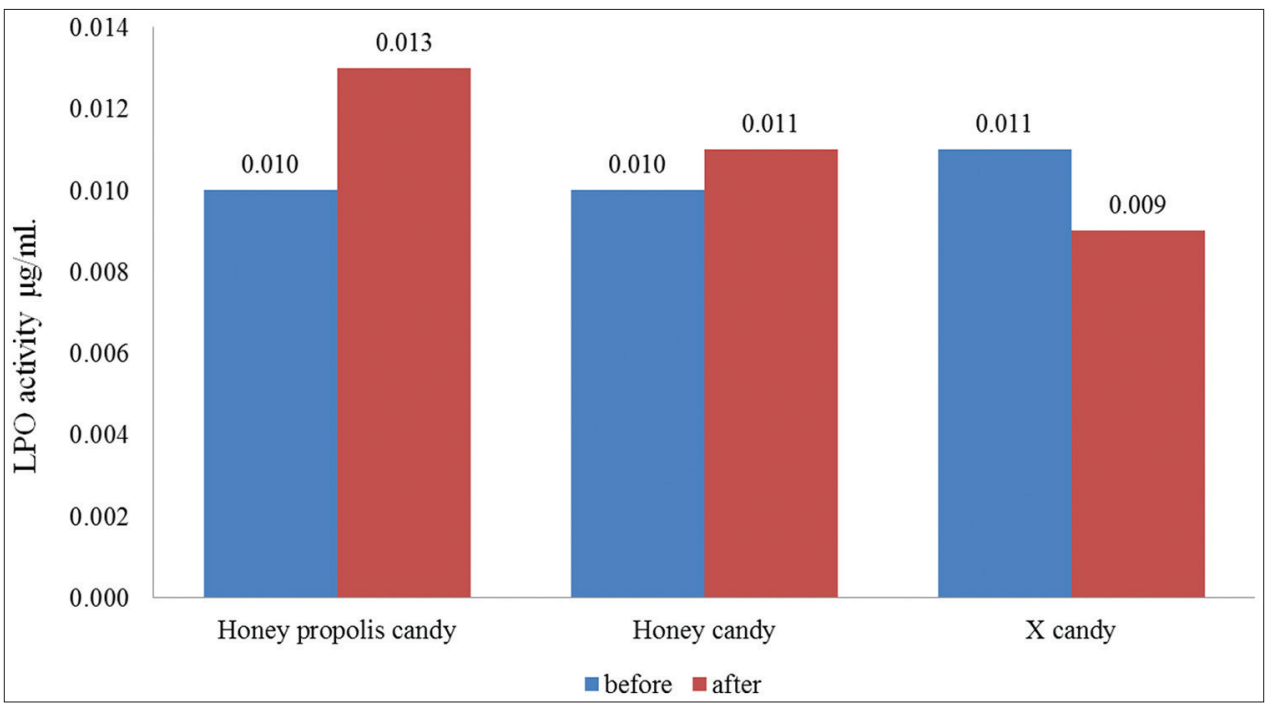

Fig. 1: Comparison of lactoperoxidase activity before and after consuming honey propolis candy, honey candy, and X candy

Table 1: LPO activity in stimulated saliva before and after treatment

\begin{tabular}{llll}
\hline $\begin{array}{l}\text { Group } \\
\text { N=40 }\end{array}$ & Average of before & Average of after & Wilcoxon (Sig.) \\
\hline Group A & $0.00973 \pm 0.003714$ & $0.01340 \pm 0.007334$ & $0.001^{*}$ \\
Mean \pm SD & & & \\
Group B & $0.00975 \pm 0.003747$ & $0.01133 \pm 0.004233$ & 0.107 \\
Mean \pm SD & & & \\
Group C & $0.01138 \pm 0.006274$ & $0.00865 \pm 0.005390$ & $0.043^{*}$ \\
Mean $\pm S D$ & & & \\
\hline${ }^{*}<<0.05$, LPO: Lactoperoxidase & &
\end{tabular}

Table 2: LPO activity before and after treatment

\begin{tabular}{ll}
\hline Group $\mathbf{n}=\mathbf{4 0}$ & $\begin{array}{l}\text { Average change of LPO activity before and after } \\
\text { treatment }\end{array}$ \\
\hline $\begin{array}{l}\text { Group A } \\
\text { Mean } \pm \text { SD }\end{array}$ & $0.00373 \pm 0.007285$ \\
$\begin{array}{l}\text { Group B } \\
\text { Mean } \pm \text { SD }\end{array}$ & $0.00160 \pm 0.005486$ \\
$\begin{array}{l}\text { Group C } \\
\text { Mean } \pm \text { SD }\end{array}$ & $0.00273 \pm 0.008262$ \\
$\begin{array}{l}\text { Kruskal-Wallis } \\
\text { Sig. }\end{array}$ & $0.001^{*}$ \\
\hline${ }^{*}<0.05$, LPO: Lactoperoxidase
\end{tabular}

\section{Statistical analysis}

Data were analyzed with SPSS 17. Data normality test was conducted using Shapiro-Wilk test. If data had normal distribution, parametric analysis was used. Statistical tests included paired $t$-test, one-way analysis of variance, and post hoc tests. If data were not normally distributed, then non-parametric analysis was used, such as Wilcoxon, Kruskal-Wallis, and Mann-Whitney tests.

\section{RESULTS}

In this study, the effect of propolis candy on LPO activity in stimulated saliva was analyzed. Saliva was sampled before and after consuming candy. Saliva was centrifuged to remove the supernatant and then reacted with $\mathrm{K}_{2} \mathrm{HPO}_{4}, \mathrm{KI}$, and $\mathrm{H}_{2} \mathrm{O}_{2}$ in a microwell and read with a microplate reader. LPO activity was calculated for the average triplo absorbance score of saliva minus the average of blank absorbance. The results are shown in Fig. 1. The LPO activity before and after consuming honey propolis candy increased by 0.004 . It increased by 0.002 after consuming honey candy and decreased by 0.003 after consuming X candy (Fig. 1).
Data were analyzed with SPSS 17. Normality testing using Shapiro-Wilk test showed that data did not have normal distribution because it had a significant score $(\mathrm{p}<0.05)$. Therefore, non-parametric tests were used. Wilcoxon and Kruskal-Wallis tests were used to analyze differences among honey propolis candy, honey candy, and X candy.

For Wilcoxon test, there was a significant difference in LPO activity before and after consuming $\mathrm{X}$ candy and honey propolis candy, shown by the significance score for $\mathrm{X}$ candy $(\mathrm{p}=0.043)$ and the significance score for honey propolis candy $(\mathrm{p}=0.001)$. Meanwhile, LPO activity before and after consuming honey candy was not significantly different $(\mathrm{p}=0.107)$ (Table 1).

According to Kruskal-Wallis test, there was a significant difference in LPO before and after consuming candy, which was significant $(\mathrm{p}=0.001)$ (Table 2). Post hoc testing was used to determine which group had significant differences. Post hoc analysis for Kruskal-Wallis test was Mann-Whitney U-test. Mann-Whitney U-test showed differences between groups: $X$ candy and propolis honey candy $(p=0.000) ; X$ candy and honey candy $(\mathrm{p}=0.022)$; and propolis honey candy and honey candy $(\mathrm{p}=0.166)$. Therefore, significant differences in LPO activity were noted between the groups consuming $\mathrm{X}$ candy and propolis honey candy, and between the groups consuming $\mathrm{X}$ candy and honey candy.

\section{DISCUSSION}

This study showed that LPO activity increases after the consumption of honey propolis candy and honey candy (Fig. 1). This may be due to the honey and glucose in the candies, with glucose composition being $41 \%$. The previous studies have showed that a honey solution activated glucose oxidase that produced $\mathrm{H}_{2} \mathrm{O}_{2}$ and increased $\mathrm{OSCN}^{-}$product, leading to increased OD scores $[8,10]$.

LPO activity after consuming honey propolis candy showed a significantly increasing score (Table 1), which is expected because propolis contains flavonoids. This is supported by a previous study stating that flavonoids contain $\mathrm{H}_{2} \mathrm{O}_{2}$ that initiates oxidative destruction of bacterial DNA [11]. $\mathrm{H}_{2} \mathrm{O}_{2}$ increases LPO activity. LPO activity after consuming honey candy does not show a significant difference (Table 1). It is suspected that this occurs because honey candy does not have propolis, and this supposition is supported by a previous study [12].

In addition, $\mathrm{LPO}$ activity after consuming $\mathrm{X}$ candy significantly decreases $(p=0.043)$ when comparing activity before and after consuming candy. This decrease in activity was observed in other studies showing that flavonoids can inhibit the growth of bacteria by destructing the permeability of cell walls, microsomes, and lysosomes of bacteria [13]. 
This leads to decrease in $\mathrm{H}_{2} \mathrm{O}_{2}$ as a bacterial product, indicating that $\mathrm{SCN}^{-}$in the LPO mechanism will not be oxidized. In other words, LPO activity will be decreased [8]. A previous study has also stated that propolis inhibits $\mathrm{H}_{2} \mathrm{O}_{2}$ production by bacteria [14]

Mann-Whitney U-test showed a significant difference in the LPO activity between $\mathrm{X}$ candy and honey propolis candy $(\mathrm{p}=0.001)$ and between $\mathrm{X}$ candy and honey candy $(\mathrm{p}=0.022)$. It is thought to be due to the candy composition. Although both have propolis, honey propolis candy has a honey and glucose composition, which forms $\mathrm{H}_{2} \mathrm{O}_{2}$. In $\mathrm{X}$ candy, glucose is replaced by low-calorie artificial sweeteners such as polydextrose, lactitol, and acesulfame-k. These are synthetic glucose components, and thus, they will not oxidize glucose. This means that no $\mathrm{H}_{2} \mathrm{O}_{2}$ products are produced in X candy, decreasing LPO activity [10].

Recent study showed that Propolis fluoride had good result in inhibit Streptococcus mutans and Enterobacter faecalis [15]. Soekanto et al showed that calcium and phosphate ion level in caries-free saliva after mastication simulation using chewing gum of Casein PhosphopeptideAmorphous Calcium Phosphate -Propolis will increased and decreased of S.mutans biofilm mass [16]. With this finding, it is necessary to further study and analyze the effectiveness of propolis in different combination to fight caries.

\section{CONCLUSIONS}

Based on this research, it can be concluded that honey propolis candy may increase LPO activity in stimulated saliva. It is also concluded that $\mathrm{X}$ candy is more effective in decreasing LPO activity in stimulated saliva than honey propolis candy and honey candy.

\section{CONFLICTS OF INTEREST}

The authors report no conflicts of interest.

\section{REFERENCES}

1. Bankova V. Chemical composition of european propolis: Expected an unexpected results. Z Naturforsch 2002;57c:530-3.
2. Lotfy M. Biological acitvity of bee propolis in health and disease. Asian Pac J Cancer Prev 2006; 7:22-31.

3. Burdock G. Review of the biological properties and the toxicity of bee propolis (propolis). Food Chem Toxicol 1997;36:347-63.

4. Hegazi AG. Propolis an Overview 2013. Available from: http://www. apinetla.com.ar/congreso/c05.pdf. [Last accessed on 2014 Jun 25]

5. Marghitas L, Dezmirean DS, Margaoan R, Mihai CM. Physicochemical characterization and antioxidant activity of transylvanian propolis. Econ Mang Financ Mark 2011;6:1228.

6. Macpherson P. The role of saliva on oral health and disease. Dent Nurs 2013;9:568-73.

7. Bosch EH, van Doorne H, de Vries S. The lactoperoxidase system: The influence of iodide and the chemical and antimicrobial stability over the period of about 18 months. J Appl Microbiol 2000;89:215-24

8. Amerongen VN. Ludah Dan Kelenjar Ludah. Yogyakarta: Gajah Mada University Press; 1991. p. 43-59.

9. Kenneth MP, Tenovuo JO. The Lactoperoxidase System Chemistry and Biological Significance. New York: Marcel Dekker; 1958.

10. Molan PC. The antibacterial activity of honey: 2 variation in the potency of the antibacterial activity. Bee World 1992;73:5-28.

11. Tsai YC, Wang YH, Liou CC, Lin YC, Huang H, Liu YC, et al. Induction of oxidative DNA damage by flavonoids of propolis: Its mechanism and implication about antioxidant capacity. Chem Res Toxicol 2012;25:191-6.

12. Sahlan MR. Hard candy propolis for oral health. [In Indonesia]. Depok: Universitas Indonesia 2011; p. 1, 2, 5.

13. Sabir A. Aktivitas antibakteri flavonoid propolis trigona sp terhadap bakteri Steptococcus mutans (in vitro). Maj Ked Gigi (Dent J) 2005; 38:135-141.

14. Cuesta A, Rodríguez A, Esteban MA, Meseguer J. In vivo effects of propolis, a honeybee product, on gilthead seabream innate immune responses. Fish Shellfish Immunol 2005;18:71-80.

15. Soekanto SA, Marpaung LJ, Himmatushohwah, Djais A, Darwita RR. Efficacy of Propolis Fluoride and Nano Silver Fluoride for Inhibition of Streptococcus mutans and Enterococcus faecalis Biofilm Formation Int J App Pharm 2017;2:51-4

16. Soekanto SA, Ghrena GCD, Bachtiar EW, Sahlan M. The Effect Of Casein Phosphopeptide-Amorphous Calcium Phosphate-Propolis Chewing Gum On Calcium and Phosphate Ion Levels in Caries-Free Subject's Saliva and Streptococcus Mutans Biofilm Formation. Asian J Pharm Clin Res. 2017.174-6. 